\title{
Parasitic fibroid: case report and novel approach in reducing incidence of future cases
}

\author{
Sukainah S.*, Nasir TK, Zulkifli K., Roziana R.
}

Department of Obstetrics and Gynaecology, Hospital Sultanah Nur Zahirah, Kuala Terengganu, Terengganu, Malaysia

Received: 26 May 2016

Revised: 21 June 2016

Accepted: 04 July 2016

\section{*Correspondence:}

Dr. Sukainah S.,

E-mail: sukainahsulaiman@yahoo.com

Copyright: $\odot$ the author(s), publisher and licensee Medip Academy. This is an open-access article distributed under the terms of the Creative Commons Attribution Non-Commercial License, which permits unrestricted non-commercial use, distribution, and reproduction in any medium, provided the original work is properly cited.

\section{ABSTRACT}

We report a case of parasitic fibroid which developed less than 1 year following laparoscopic myomectomy using power morcellation. Following this case, a novel approach in reducing the incidence of future parasitic fibroid is described.

Keywords: Parasitic fibroid post morcellation, Morcellation above the plastic bag, Prevent parasitic fibroid

\section{INTRODUCTION}

Uterine myoma is a common gynaecological disorder occurring in $20-50 \%$ of women of late reproductive age. ${ }^{1}$ Surgical interventions are recommended for symptomatic patients and advances in surgical equipment have facilitated minimally invasive endoscopic surgery. ${ }^{2}$ Laparoscopic morcellation is often used for tissue removal after laparoscopic myomectomy and may result in parasitic myoma. This is due to seeding of the remaining tissue fragments in the abdominal cavity which become adherent to surrounding structures and develop an auxiliary blood supply. ${ }^{3}$ The incidences of parasitic fibroids are rare and Huang et al describe only 1 case out of 466 laparoscopic myomectomies in their series. ${ }^{4}$ Although rare, the occurrences of parasitic fibroids pose significant diagnosis challenge and management to the clinician.

\section{CASE REPORT}

A 29 year old primigravida at 29 weeks pregnancy was seen with abdominal pain. Approximately 4 months prior to conception the patient underwent laparoscopic myomectomy for a $10 \times 12 \mathrm{~cm}$ uterine fibroid. Power morcellator was used to remove the fibroid. Postoperative period was uneventful.
She conceived spontaneously after operation however first trimester ultrasound detected recurrence of intramural fibroid of $5 \times 5 \mathrm{~cm}$. She remained asymptomatic until 29 weeks when she developed severe abdominal pain necessitating ward admission. Diagnosis of red degeneration of uterine fibroid was made and she received oral and parenteral analgesics. Despite analgesics, the pain did not disappear. In view of persistent troublesome abdominal pain and inability to exclude myomectomy scar dehiscence, we decided for delivery via caesarean section at 31 weeks.

Intraoperative, the previous myomectomy scar was intact but multiple parasitic fibroids with varying sizes from 2 $\mathrm{cm}$ to $15 \mathrm{~cm}$ were found at the pelvic side wall, previous trocar site and mesentery (Figure 1-4). All visible parasitic fibroids were excised and histopathology confirmed leiomyoma.

\section{DISCUSSION}

Fibroid or leiomyoma is one of the common diseases of female reproductive system. Parasitic fibroid is a rare subtype of fibroid. Spontaneous parasitic fibroid is extremely rare however few cases of parasitic fibroid post morcellation have been reported..$^{5}$ Spontaneous parasitic fibroid may result from detached subserosal fibroid which takes blood supply from surrounding organs like 
omentum or mesentery. ${ }^{6}$ Iatrogenic parasitic fibroid on the other hand may rise from the remnant of myoma tissue post laparoscopic myomectomy which grows and takes blood supply from the adjacent organ. ${ }^{7}$

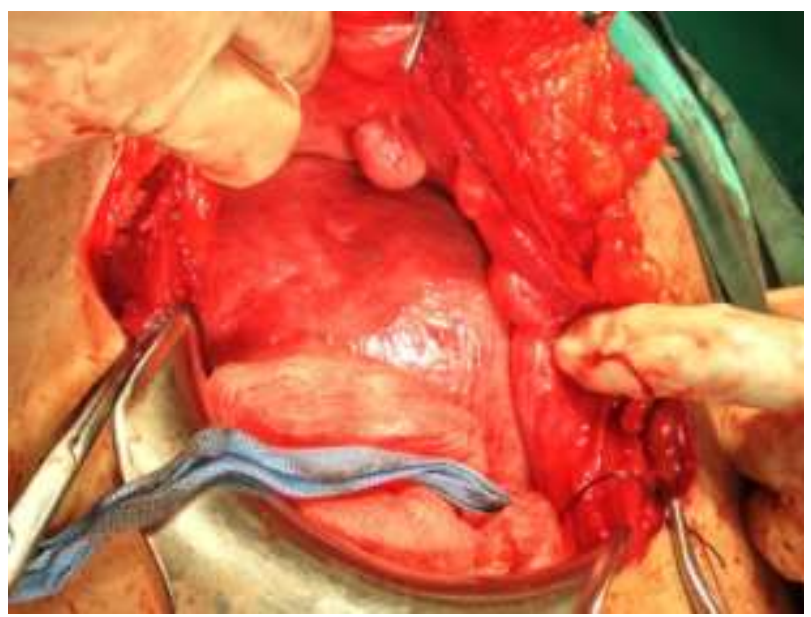

Figure 1: Parasitic fibroid at previous trocar site.

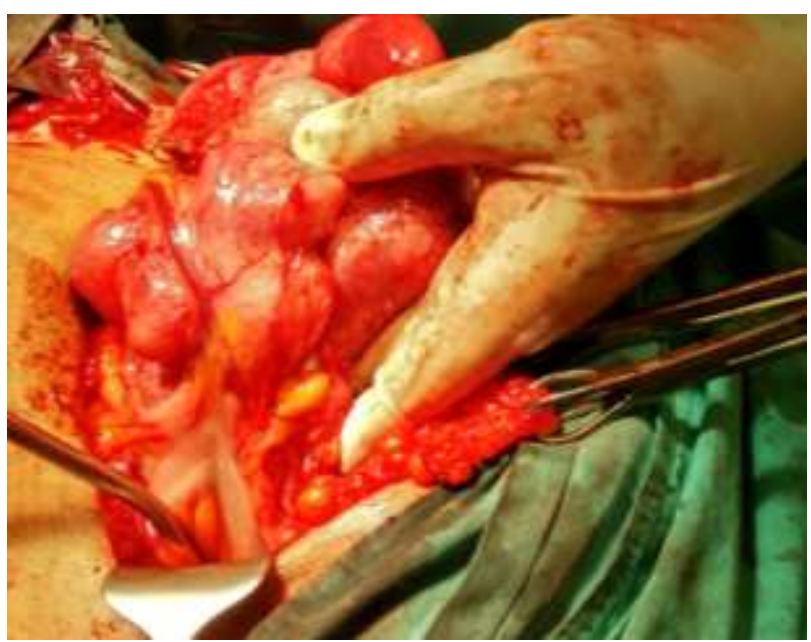

Figure 2: Parasitic fibroid at bowel mesentery.

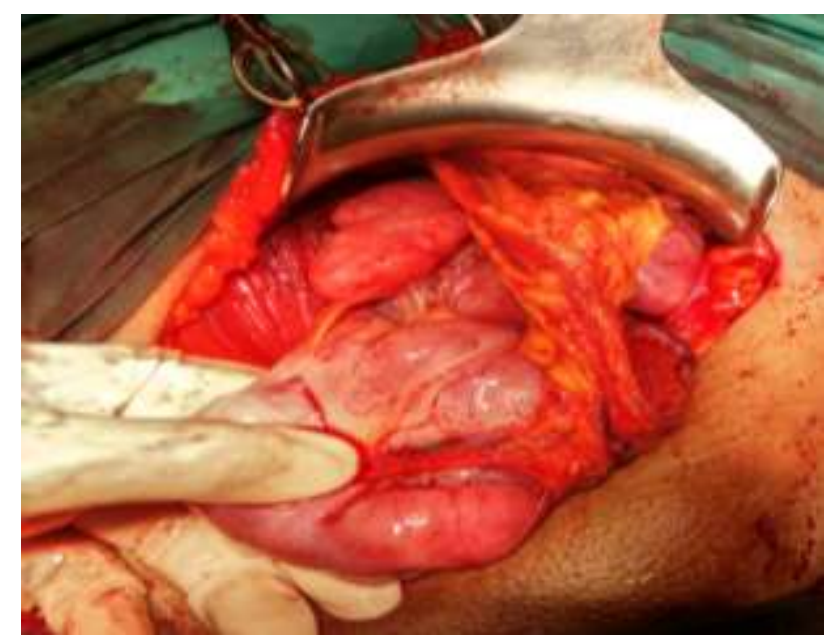

Figure 3: Parasitic fibroid with blood supply from omental vessels.

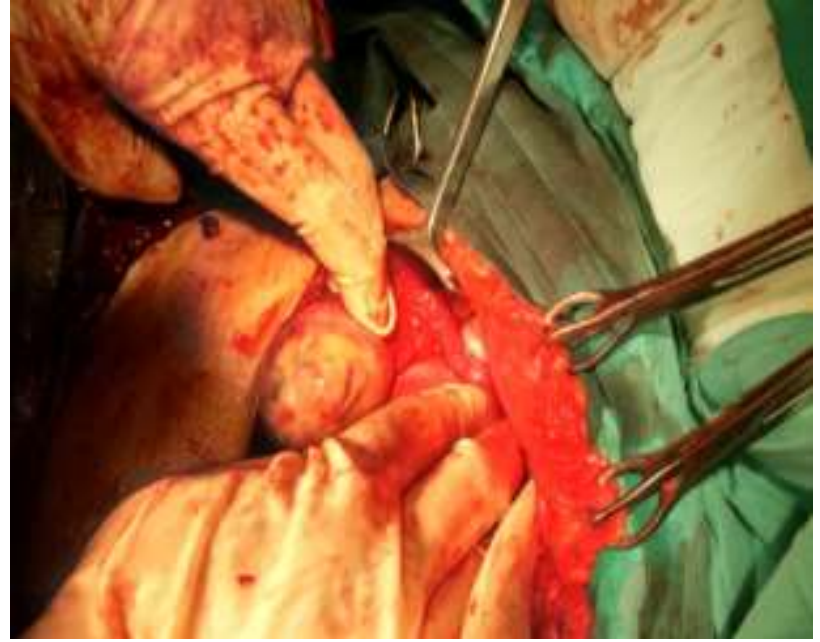

Figure 4: Parasitic fibroid at right pelvic wall.

Cucinella et al quoted the incidence of parasitic fibroid following laparoscopic myomectomy to be $1.2 \%$. The most frequent sites for parasitic fibroid were the pelvic parietal peritoneum, the anterior parietal peritoneum at the level of the rectus, and along the gastrointestinal tract. Others localizations included the left paracolic fossa and the peritoneum at the level of the promontory of sacrum. ${ }^{8}$

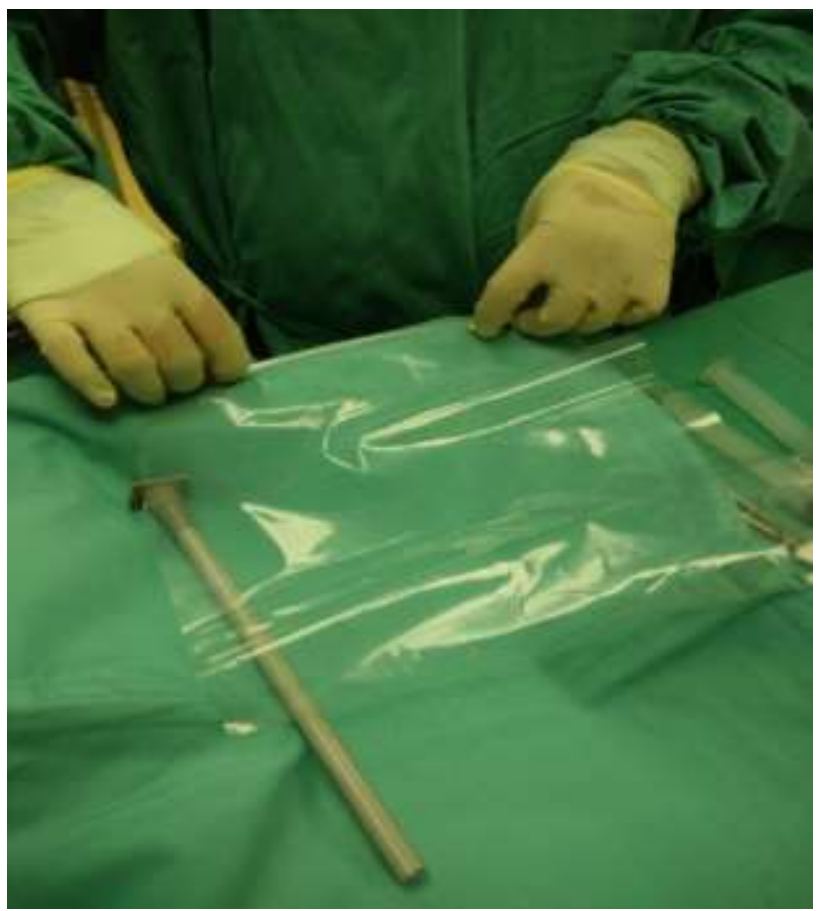

Figure 5: Sterilized plastic bag.

Morcellation in a bag is the latest technique described to reduce risk of spreading or leaving behind the morcellated tissue. ${ }^{9}$ However morcellation bag is not cheap and not readily available in many low resource laparoscopic centres. 


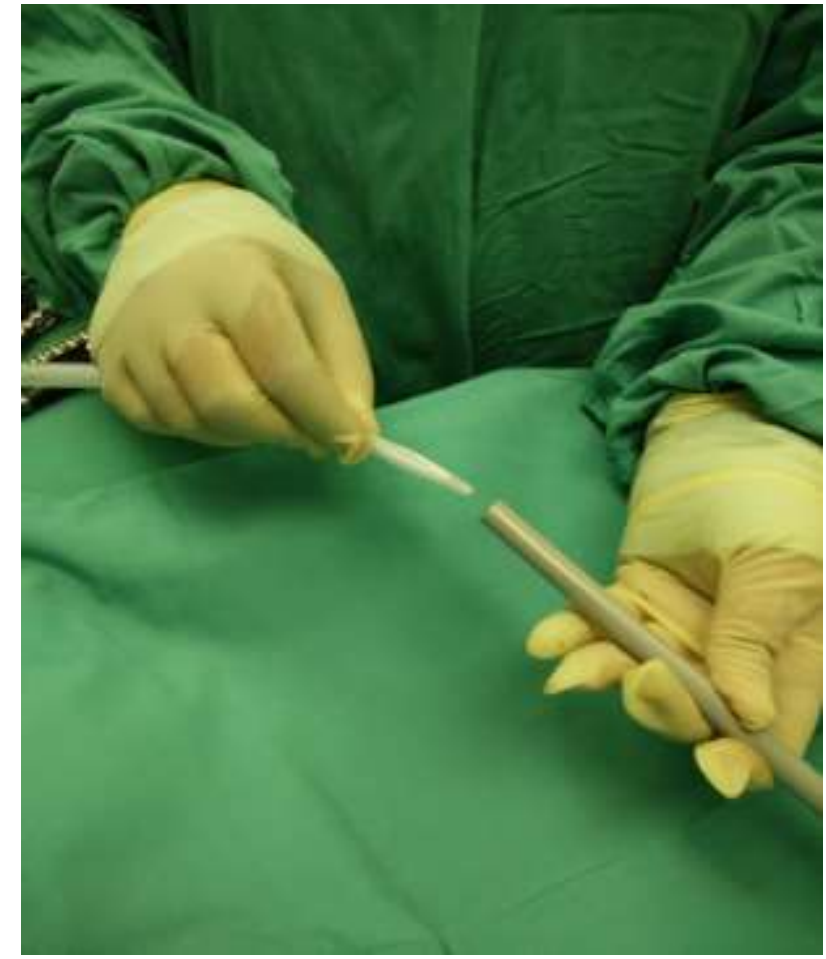

Figure 6: Inserting folded plastic bag into canister.

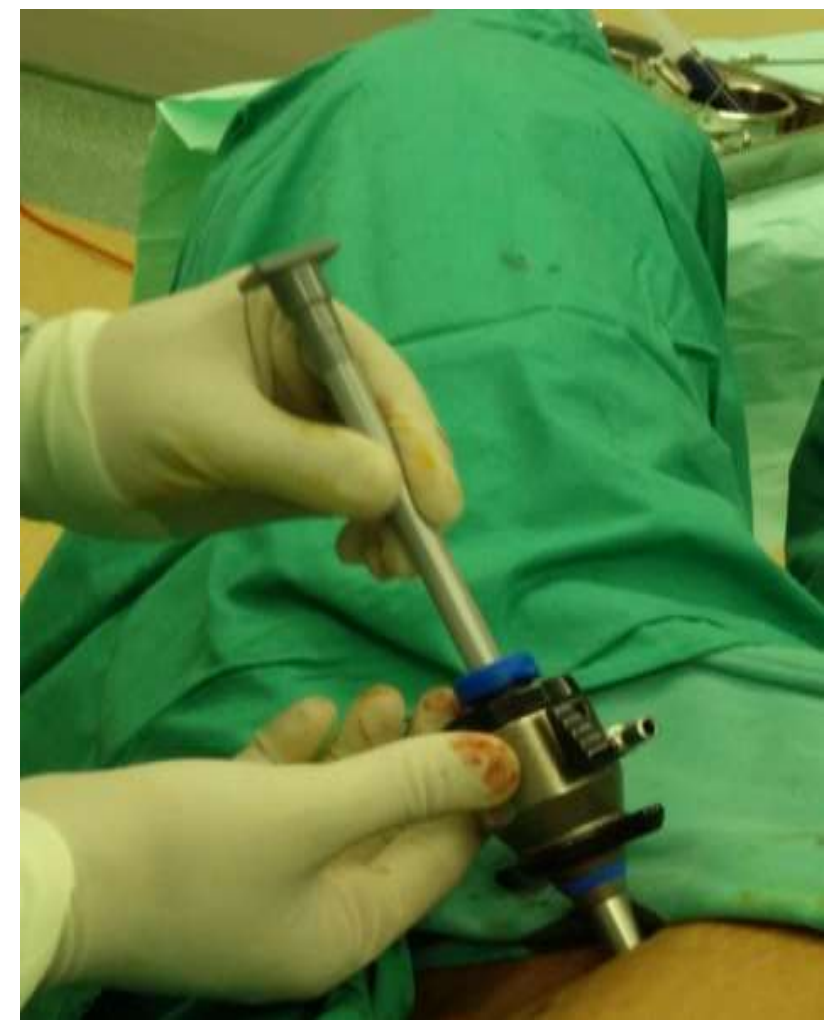

Figure 7: Inserting sterilized plastic bag into peritoneal cavity.

To address the issue, we started using sterilized plastic bag to cover the bowels and pelvic organs during morcellation process (Figure 5). The plastic bag is cut into a rectangular shape, fitted into an empty endo-pouch applicator and introduced into the peritoneal cavity to cover the bowel and pelvic organs (Figure 6, 7). Morcellation is done above the plastic cover. Debris of morcellated tissue would easily be picked up by grasping forceps as the plastic cover prevents spillage especially between bowel loops (Figure 8-10). Most of the tiny debris also adheres to the surface of plastic cover and is removed together upon a complete procedure. Tiny debris could also be irrigated out since the plastic cover facilitates easier irrigation.

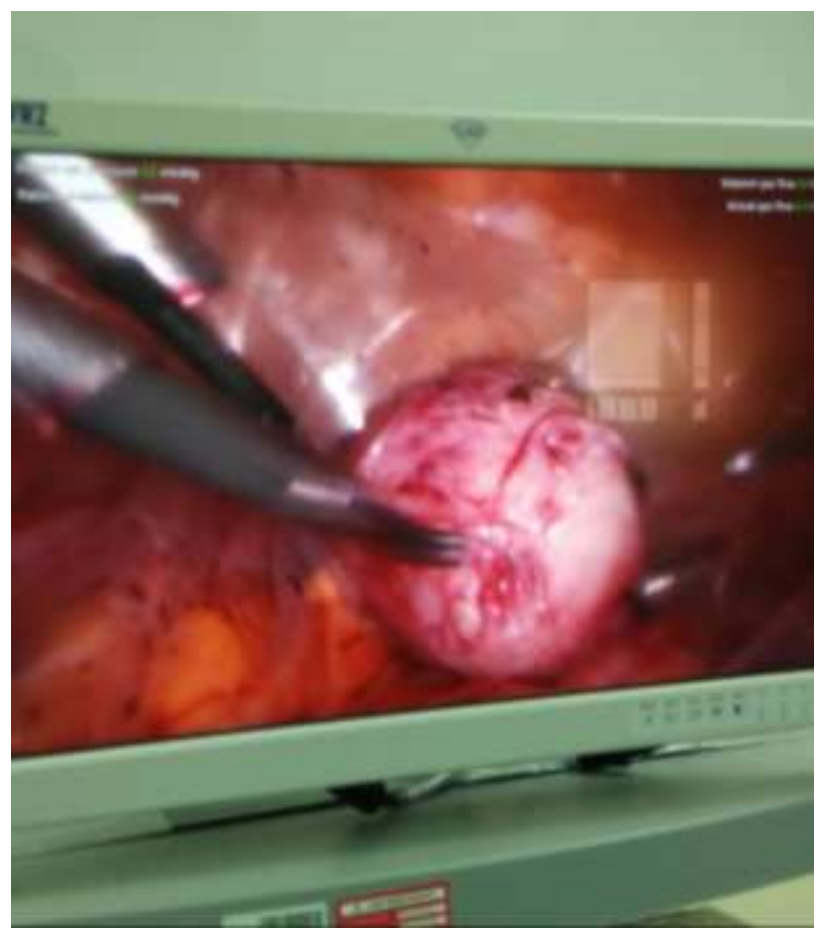

Figure 8: Uterine fibroid prior to morcellation.

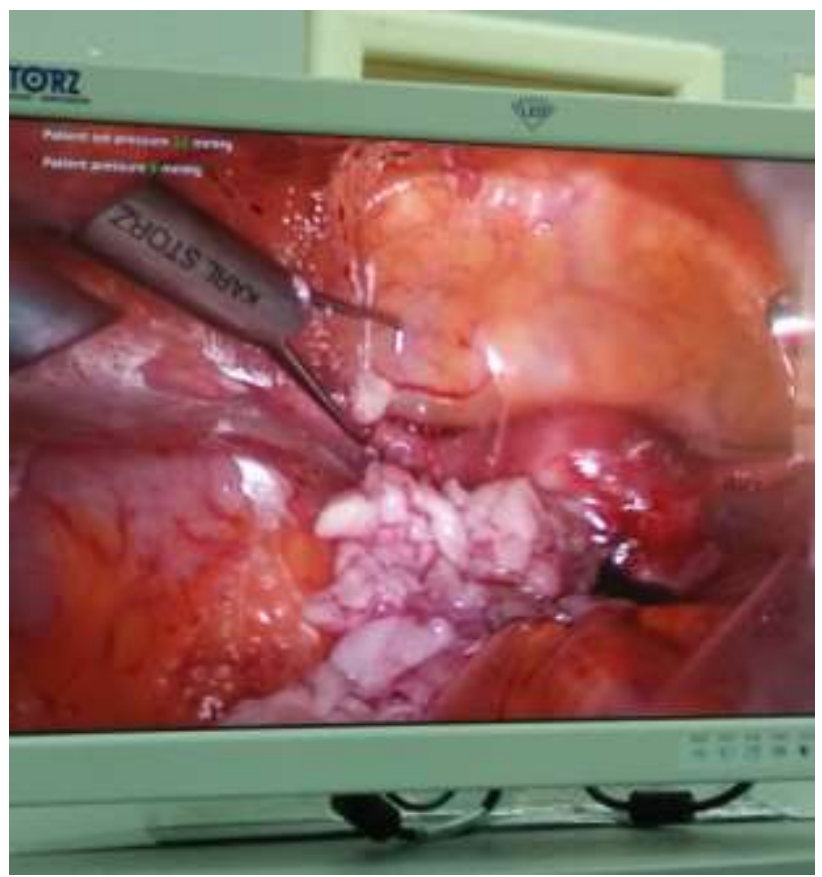


Figure 9: Tissue debris.

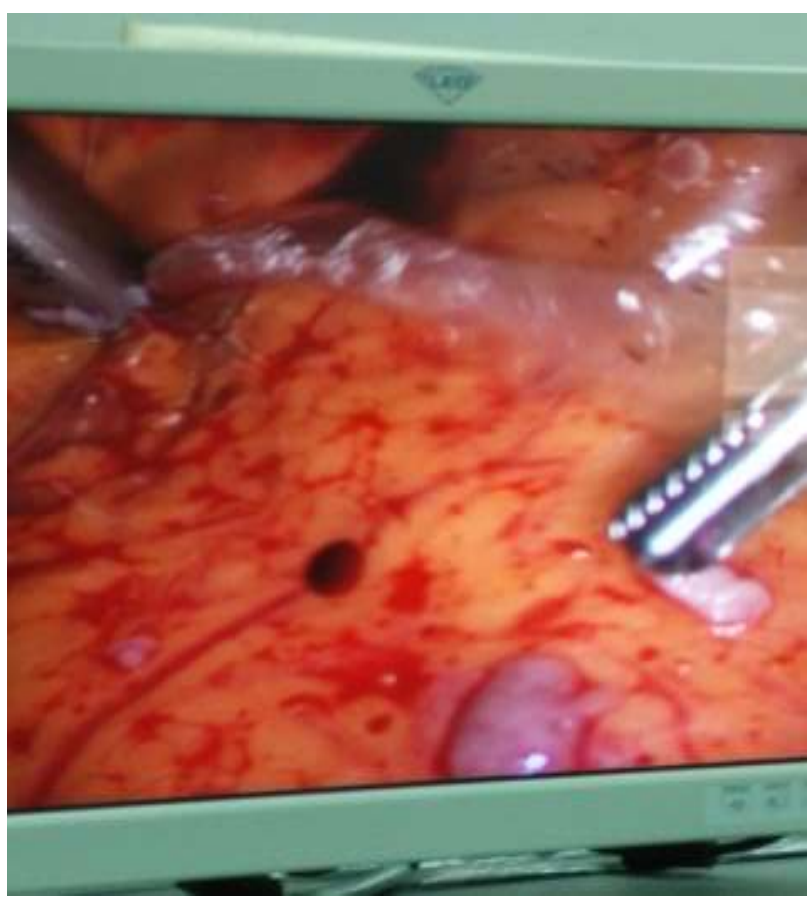

Figure 10: Tissue debris picked up by grasping forceps.

\section{CONCLUSION}

With the increase in minimally invasive gynaecological surgery, the incidence of parasitic fibroid post morcellation will definitely increase. In-bag morcellation is the latest technique described to prevent this complication, but it is expensive and not readily available in all laparoscopic centres.

The use of a cheap plastic during morcellation as described here may reduce the likelihood of future parasitic fibroids. We recommend this technique to be used in a low resource laparoscopic centre.
Funding: No funding sources Conflict of interest: None declared Ethical approval: Not required

\section{REFERENCES}

1. Stovall TG, Myomectomy. In: Mann WJ, Stovall TG, editors. Gynaecologic Surgery. Churchill Livingstone, New York. 1996;445-461.

2. Hurst BS, Matthews ML, Marshburn PB. Laparoscopic myomectomy for symptomatic uterine myomas. Fertility and Sterility. 2005;85:1-23.

3. Zaitoon MM. Retroperitoneal parasitic leiomyoma causing unilateral ureteral obstruction. Journal Urology. 1986;135:130-1.

4. Pei-Shen H, Wen-Chun C, Su-Chen H. Iatrogenic parasitic fibroid: A case report and review of literature. Taiwanese Journal of Obstetrics and Gynaecology. 2014;53:392-6.

5. Elsayed MA. Primary parasitic myoma in a young virgin. Middle East Fertility Society Journal. 2015;20:213-5.

6. Elagwany AS, Rady HA, Abdeldayem TM. A case of parasitic leiomyoma with serpentine omental blood vessels: An unusual variant of uterine leiomyoma. Journal of Taibah University Medical Sciences. 2014;9(4):338-40.

7. Ostrzenski A. Uterine leiomyoma particle growing in an abdominal-wall incision after laparoscopic retrieval. The American College of Obstetricians and Gynaecologist. 1997;89(5 Pt. 2):853-4.

8. Cucinella G, Granese R, Calagna G, Somigliana E, Perino A. Parasitic myomas after laparoscopic surgery: an emerging complication in the use of morcellator. Description of four cases. Fertility and Sterility. 2011;96:90-6.

9. McKenna JB, Kanade T, Choi S. The Sydney contained in bag morcellation technique. The Gynaecology. 2014;21(6):984-5.

Cite this article as: Sukainah S, Nasir TK, Zulkifli K, Roziana R. Parasitic fibroid: case report and novel approach in reducing incidence of future cases. Int $\mathbf{J}$ Reprod Contracept Obstet Gynecol 2016;5:2836-9. 